\title{
Penerapan E-Customer Relationship Pada PT. Kimia Farma Berbasis Web
}

\author{
Application of E-Customer Relationship at PT. Kimia Farma Web Based \\ Bagus Pramana Putra ${ }^{1}$ Evri Ekadiansyah ${ }^{2}$ \\ ${ }^{1}$ Program Studi Sistem Informasi Universitas Potensi Utama \\ ${ }^{2}$ Dosen Program Studi Sistem Informasi Universitas Potensi Utama \\ ${ }^{1,2}$ Universitas Potensi Utama, K.L. Yos Sudarso KM 6,5 No. 3A Tj. Mulia - Medan \\ E-mail:baguspramana@gmail.com ${ }^{1}$, evrie1409@gmail.com²
}

ABSTRAK

Hasil penjualan PT. Kimia Farma dipasarkan hingga sekitaran luar kota. Seiring dengan misi perusahaan untuk meningkatkan kepuasan dan membina hubungan baik dengan pelanggan, maka dibutuhkan suatu konsep manejem customer yang baik. Sistem yang berjalan pada perusahaan masih menggunakan aplikasi sederhana, sehingga pelanggan yang akan memesan produk harus datang langsung atau menghubungi pihak perusahaan untuk melakukan proses pemesanan produk, kemudian pihak perusahaan akan konfirmasi pemesanan produk, setelah itu melakukan proses pembayaran pemesanan produk dengan datang langsung pada perusahaan. Seiring dengan misi perusahaan untuk meningkatkan kepuasan management customer yang baik. Salah satu konsep yang dapat diadopsi untuk merespon hal ini adalah dengan menerapkan suatu Customer Relationship Management yang dapat menghubungkan perusahaan dan customer secara langsung (online) yang disebut E-CRM. Ada banyak sekali alasan mengapa penerapan ECRM sangat penting untuk perusahaan. Melalui pengunaan E-CRM perusahaan bisa mendapatkan manfaat untuk penjualan, pemasaran, pelayanan dan juga aktivitas perusahaan lainnya. E-CRM juga dapat mempermudah pelanggan dalam mendapatkan informasi yang diperlukan dari perusahaan tersebut. Hal ini menjadi sarana untuk mempertahankan hubungan perusahaan dengan pelanggan demi mewujudkan loyalitas pelanggan, dengan merancang system yang baru maka pelanggan dan pihak perusahaan akan dapat melakukan kerja sama yang baik dengan transaksi pemasaran.

Kata Kunci : E-CRM, PHP, Mysql

\section{ABSTRACT}

The sales proceeds of PT. Kimia Farma is marketed to areas outside the city. Along with the company's mission to increase satisfaction and maintain good relationships with customers, a good customer management concept is needed. The system that runs at the company still uses a simple application, so customers who will order products must come directly or contact the company to carry out the product order process, then the company will confirm the product order, after that make the product order payment process by coming directly to the company. Along with the company's mission to increase satisfaction with good customer management. One of the concepts that can be adopted in response to this is by implementing a Customer Relationship Management that can connect companies and customers directly (online) called E$C R M$. There are many reasons why implementing E-CRM is so important for companies. Through the use of E-CRM, companies can get benefits for sales, marketing, service and other company activities. E-CRM can also make it easier for customers to get the necessary information from the company. This is a means to maintain company relationships with customers in order to achieve customer loyalty, by designing a new system, customers and the company will be able to work together well with marketing transactions.

Keywords: E-CRM, PHP, Mysql 


\section{PENDAHULUAN}

Customer Relationship Management (CRM) merupakan salah satu sarana untuk menjalin PT. Kimia Farma merupakan perusahaan yang bergerak di bidang penjualan obat. Pada PT. Kimia Farma konsumen sering mengeluh dengan pelayanan yang ada, sehingga konsumen merasa tidak puas dengan pelayanan yang diberikan oleh PT. Kimia Farma. Hal tersebut terjadi karena sistem yang berjalan pada perusahaan masih bersifat semi komputerisasi, dan pengisian kuesioner masih dilakukan secara manual. Untuk mengatasi kendala yang dihadapi, maka dibutuhkan suatu sistem yang khusus tentang manejemen customer, dengan menerapkan Electronic Customer Relationship Management maka pelanggan dapat meyampaikan complain/ keluhan secara online tanpa memakan waktu yang cukup lama serta mempermudah perusahaan dalam membuat rating keluhan pelanggan dalam pelayanan pada PT. Kimia Farma Medan. Hasil dari penelitian ini adalah aplikasi E-Customer Relationship Management pada PT. Kimia Farma yang dapat diakses secara online sebagai informasi bagi perusahaan dan customer. E-CRM juga dapat mempermudah pelanggan dalam mendapatkan informasi yang diperlukan dari perusahaan tersebut. Hal ini menjadi sarana untuk mempertahankan hubungan perusahaan dengan pelanggan demi mewujudkan loyalitas pelanggan, dengan merancang system yang baru maka pelanggan dan pihak perusahaan akan dapat melakukan kerja sama yang baik.

Seiring dengan perkembangan teknologi, CRM juga mengalami perkembangan. CRM yang awalnya mengelola hubungan pelanggan dengan bertemu secara langsung, kini bisa dilakukan melalui media elektronik atau disebut Electronic Customer Relationship Management (E-CRM). Bentuk E-CRM berupa media online yang paling umum digunakan adalah website portal perusahaan dikarenakan kemudahan dalam membuat website, biaya yang tidak terlalu mahal, dan dapat diakses oleh siapa saja.

E-CRM (Electronic Customer Relationship Management) adalah suatu usaha mengelola relasi antara perusahaan dengan pelanggan dalam rangka peningkatan loyalitas pengkonsumsian produk-produk yang diproduksi oleh perusahaan dengan memanfaatkan peralatan elektonik seperti TV, Radio, Telepon dan Internet. CRM, menjadi amat berharga ketika kompetisi meningkat dan jumlah pelanggan makin banyak. Teknologi E-CRM yang tepat dan memadai akan membantu permasalahan yang dihadapi perusahaan terkait bagaimana meningkatkan loyalitas perusahaan terhadp pelanggan.

\section{METODE PENELITIAN}

Penulis melakukan pengumpulan data-data yang berkaitan dengan penelitian penulis guna mendapatkan data-data dan informasi tentang permasalahan perusahaan yang berdasarkan teori Customer Relationship Management. Pengumpulan data yang dilakukan diantaranya :

1. Studi Pustaka (Library Reasearch)

Pada studi ini penulis mengutip dari beberapa bacaan yang berkaitan dengan E-Customer Relationship Management. Pengutipan yang dilakukan dapat berupa teori ataupun beberapa pendapat dari beberapa buku bacaan ataupun buku diktat yang dipergunakan selama kuliah. Hal ini dimaksudkan untuk memberikan landasan teori yang kuat melalui buku-buku atau literatur yang penulis gunakan.

2. Studi Lapangan (Field Research)

Studi lapangan dilakukan dengan cara melibatkan pihak-pihak yang berkompeten dalam Customer Relationship Management. Hal ini dilakukan untuk mendapatkan data-data dan keterangan-keterangan yang berhubungan dengan permasalahan yang di teliti. Studi lapangan meliputi :
a. Observasi (Pengamatan Langsung)
Pada bagian ini penulis mengamati proses penyampaian informasi yang diberikan kepada customer dari bagian customer service baik melalui percakapan langsung dengan customer atau melalui telepon.
b. Interview (Wawancara) 
Pada bagian ini dilakukan proses wawancara langsung dengan manajemen PT. Kimia Farma untuk mendapatkan informasi - informasi seperti: sistem yang sedang berjalan, dan kelemahan dari sistem yang ada sehingga perlu dibuatkan sistem yang baru pada pada PT.Kimia Farma. Adapun wawancara yang dilakukan adalah sebagai berikut :

1. Bagaimana sistem yang berjalan pada PT. Kimia Farma dalam mengatur dan menjalin hubungan baik antara perusahaan dan customer?

Jawab : Agar hubungan baik antara perusahaan dan customer dapat terjalin dengan baik, perusahaan menggunakan layanan customer service yang dapat dimanfaatkan oleh customer untuk mendapatkan informasi.

2. Apakah permasalahan yang ditemui selama ini dalam penanganan customer? Jawaban : Untuk mendapatkan informasi dan pengetahuan seputar perusahaan, customer harus datang langsung ke perusahaan dengan mengajukan pertanyaan ke layanan customer service perusahaan.

3. Bagaimana solusi yang diharapkan untuk mengatasi permasalahan tersebut ?

Jawaban : Perusahaan membutuhkan aplikasi yang dapat diakses secara online sebagai pintu gerbang pusat dalam hal menjalin komunikasi yang baik dengan customer sehingga dapat meningkatkan pelayanan kepada customer.

Pengembangan sistem dapat berupa menyusun suatu sistem yang baru dan menggantikan sistem yang lama secara keseluruhan atau memperbaiki sistem yang telah ada.

1. Analisis Kebutuhan

Berisi tentang hal-hal yang harus ada pada hasil perancangan agar mampu menyelesaikan masalah yang ada sesuai tujuan. Data yang dibutuhkan dalam melakukan perancangan sistem adalah data penjualan obat, data customer, data pengguna dan bahasa pemrograman yang digunakan untuk membuat aplikasi adalah $P H P$.

2. Desain Sistem

Secara umum perancangan sistem pada Penerapan Penerapan E-Customer Relationship Management Pada PT.Kimia Farma menggunakan model perancangan Unified Modelling Language yaitu use case diagram, class diagram, activity diagram dan sequence diagram.

3. Tools

Adapun perangkat yang digunakan oleh peneliti yang digunakan untuk membangun sistem yang baru adalah perseonal computer core I3, PHP dan MySql.

4. Metode

Penulis memilih Penerapan E-Customer Relationship Management dalam menyelesaikan laporan penelitian ini dan sangat tepat dalam menyelesaikan permasalahan yang dihadapi oleh perusahaan.

5. Pengujian Program

Pada tahap ini dilakukan pengujian aplikasi secara menyeluruh, meliputi pengujian fungsional dan pengujian ketahanan sistem. Pengujian secara black box (interface) yaitu pengujian perangkat lunak yang tes fungsionalitas dari aplikasi yang bertentangan dengan struktur internal atau kerja. Pengetahuan khusus dari kode aplikasi atau struktur internal dan pengetahuan pemrograman pada umumnya tidak diperlukan, pengujian tersebut untuk masing-masing blok peralatan yang dirancang.

6. People

Pada tahap ini E-Customer Relationship Management pada PT. Kimia Farma sudah melewati tahap validasi dan verifikasi dan siap untuk digunakan oleh PT. Kimia Farma dan customer dan peneliti.

\section{HASIL DAN PEMBAHASAN}

PT. Kimia Farma merupakan perusahan yang memiliki kewajiban penuh dalam pelayanan customer dalam pemberian obat. Konsumen sering merasa tidak puas dengan pelayanan yang ada pada PT. Kimia Farma, dan konsumen harus datang langsung pada lokasi PT. Kimia Farma untuk menyampaikan segala keluhan sama pihak customer service. Proses pelayanan yang berjalan 
adalah konsumen sering mengeluh dengan pelayanan yang ada, sehingga konsumen merasa tidak puas dengan pelayanan yang diberikan oleh PT. Kimia Farma baik dari segi pelayanan langsung maupun tidak langsung. Pihak PT. Kimia Farma sering menyampaikan pelayanan pada pelanggan yang kurang baik dari segi penyampaian promosi produk obat pada PT. Kimia Farma. Sehingga pelanggan kurang puas terhadap pelayanan yang ada pada PT. Kimia Farma. Untuk mengatasi kendala yang dihadapi, maka dibutuhkan suatu sistem yang khusus tentang manejemen customer, dengan menerapkan Electronic Customer Relationship Management maka pelanggan dapat meyampaikan complain/ keluhan secara online tanpa memakan waktu yang cukup lama serta mempermudah perusahaan dalam membuat rating keluhan pelanggan dalam pelayanan pada PT. Kimia Farma Medan. Hasil dari penelitian ini adalah aplikasi E-Customer Relationship Management pada PT. Kimia Farma yang dapat diakses secara online sebagai informasi bagi perusahaan dan customer.

Secara garis besar, bisnis proses sistem yang akan dirancang digambarkan dengan usecase diagram yang terdapat pada Gambar 1 :

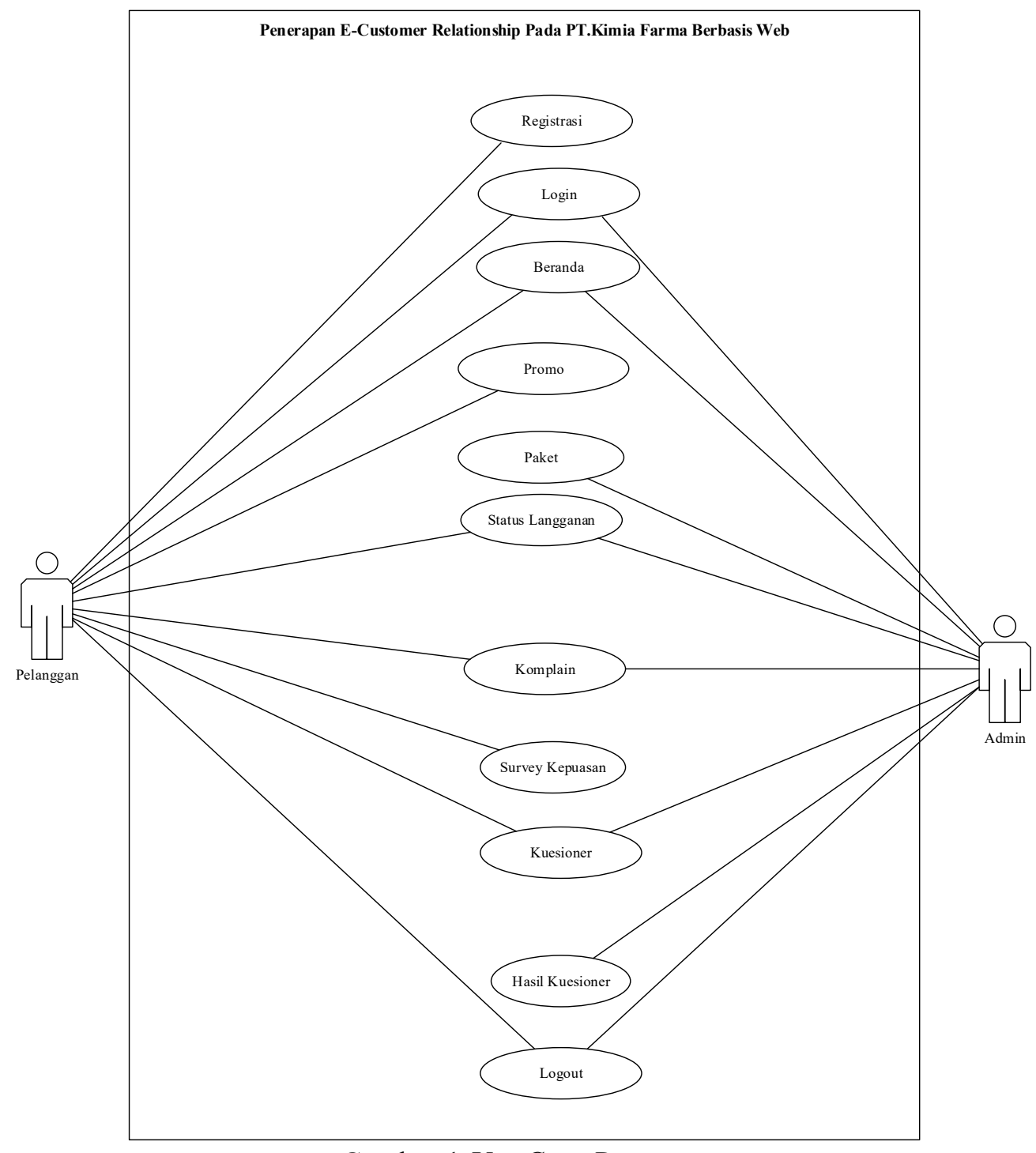

Gambar 1 Use Case Diagram

Rancangan kelas-kelas yang akan digunakan pada sistem yang akan dirancang dapat dilihat pada gambar 2 : 


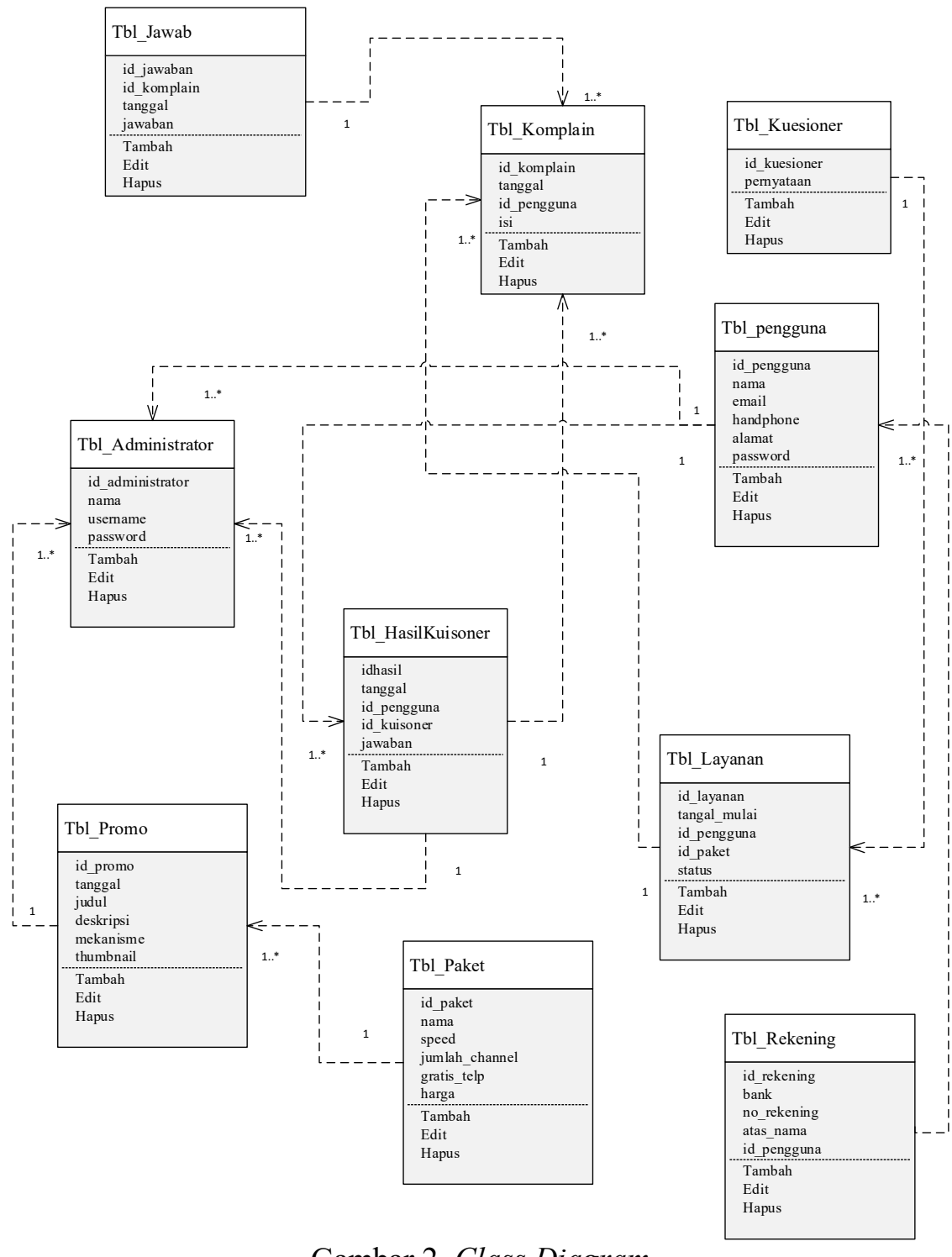

Gambar 2. Class Diagram

\subsection{Tampilan Hasil}

1. Tampilan Form Input Data Pengguna

Tampilan ini merupakan tampilan form input data pengguna yang berfungsi untuk mengisi data-data pengguna. Berikut gambar form input data pengguna ditunjukkan pada 3 :

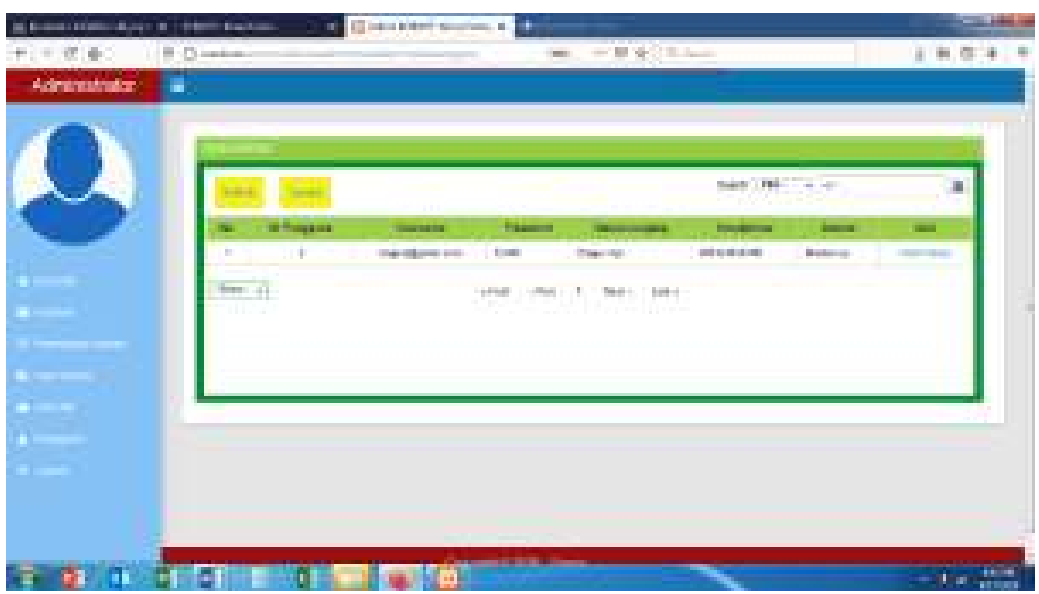

Gambar 3. Tampilan Form Data Input Pengguna 
2. Tampilan Form Kategori Produk

Tampilan ini merupakan tampilan form data kategori produk yang berfungsi untuk menampilkan data-data kategori produk. Berikut gambar form data kategori produk ditunjukkan pada 4 :

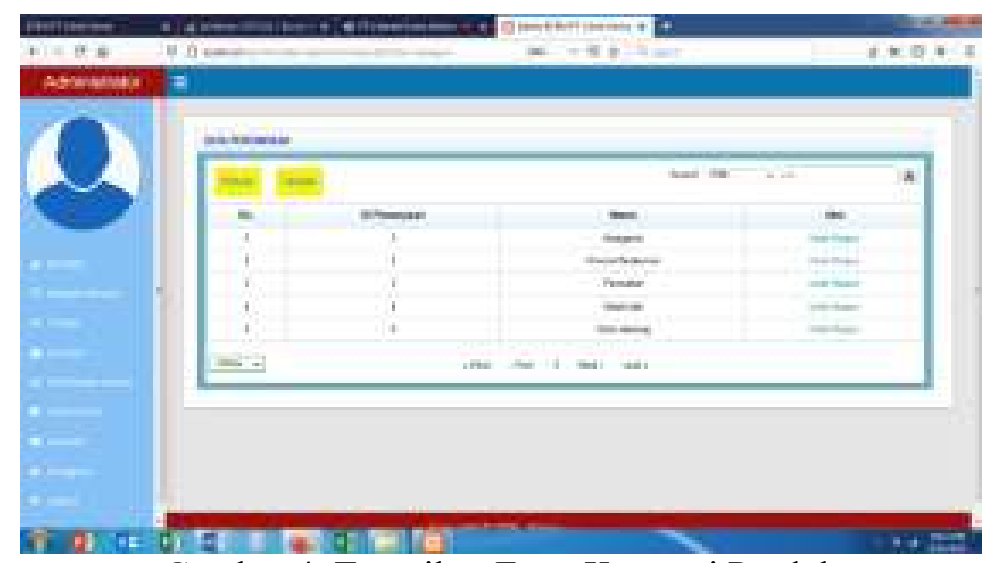

Gambar 4. Tampilan Form Kategori Produk

3. Tampilan Form Produk

Tampilan ini merupakan tampilan form data produk yang berfungsi untuk menampilkan data-data produk. Berikut gambar form data produk ditunjukkan pada 5 :

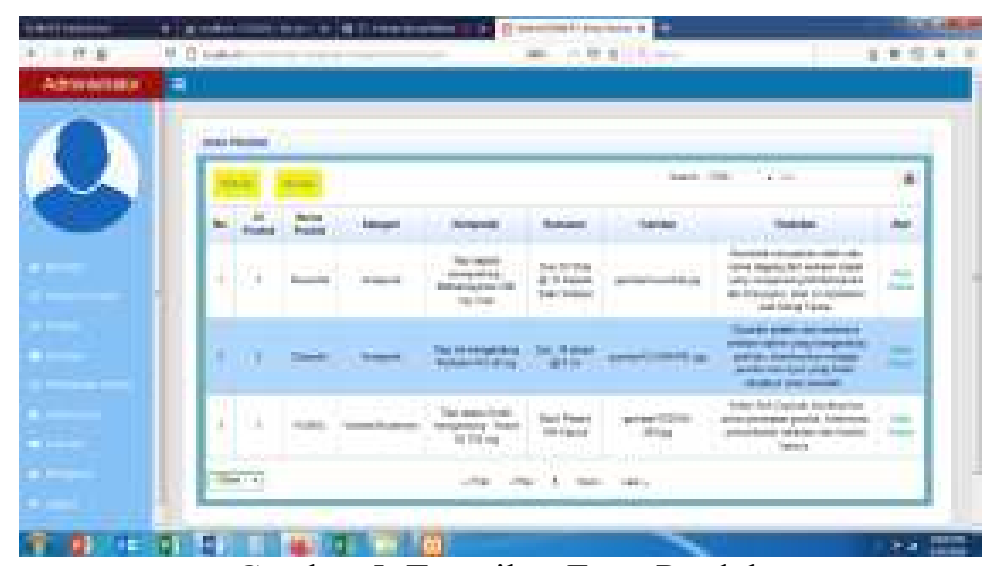

Gambar 5. Tampilan Form Produk

4. Tampilan Form Keluhan

Tampilan ini merupakan tampilan form data Keluhan yang berfungsi untuk menampilkan data-data Keluhan. Berikut gambar form data Keluhan ditunjukkan pada 6 :

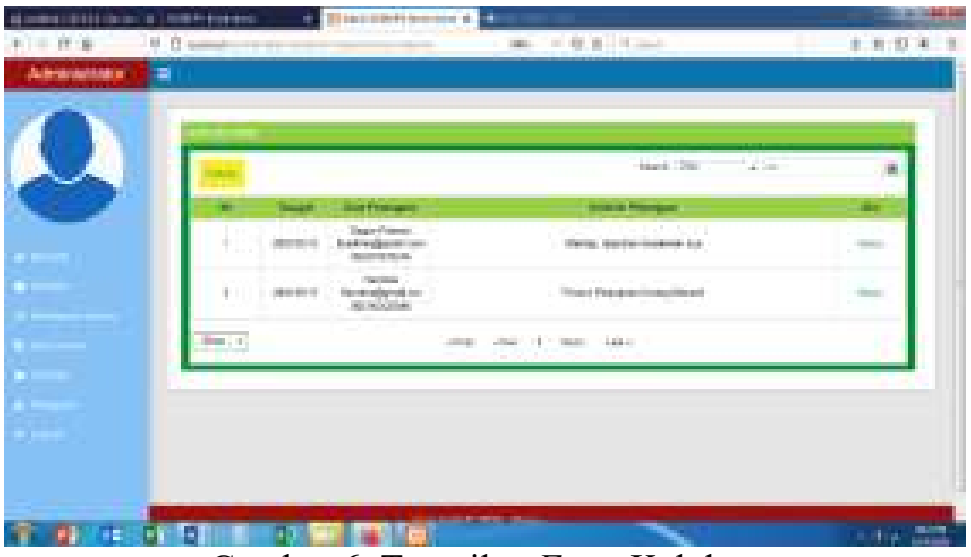

Gambar 6. Tampilan Form Keluhan 
5. Tampilan Form Pernyataan Survey

Tampilan ini merupakan tampilan form data Pernyataan Survey yang berfungsi untuk menampilkan data-data Pernyataan Survey. Berikut gambar form data Pernyataan Survey ditunjukkan pada 7 :

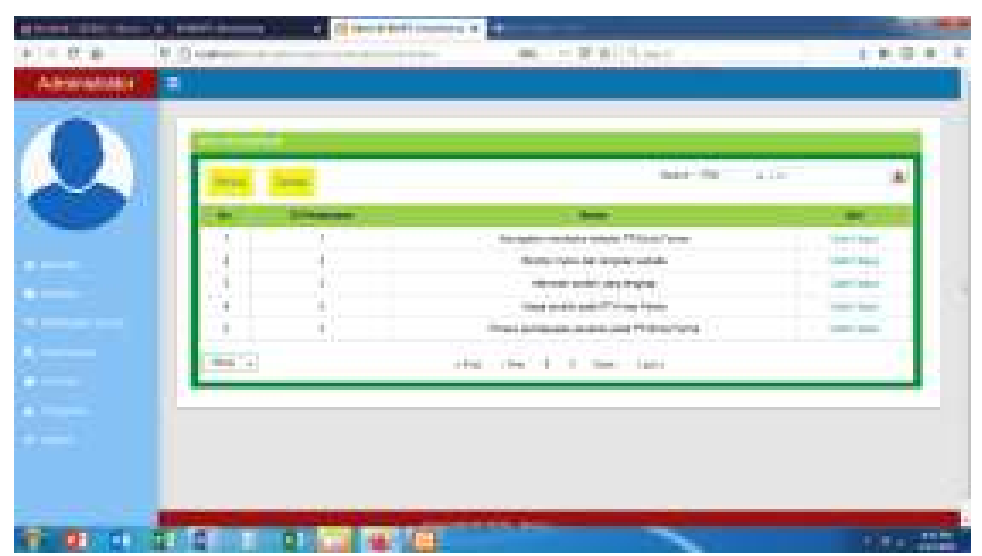

Gambar 8. Tampilan Form Pernyataan Survey

6. Tampilan Form Keluhan/ Komplain

Tampilan ini merupakan tampilan form input data Keluhan/ Komplain yang berfungsi untuk mengisi data-data Keluhan/ Komplain. Berikut gambar form input data Keluhan/ Komplain ditunjukkan pada 9 :

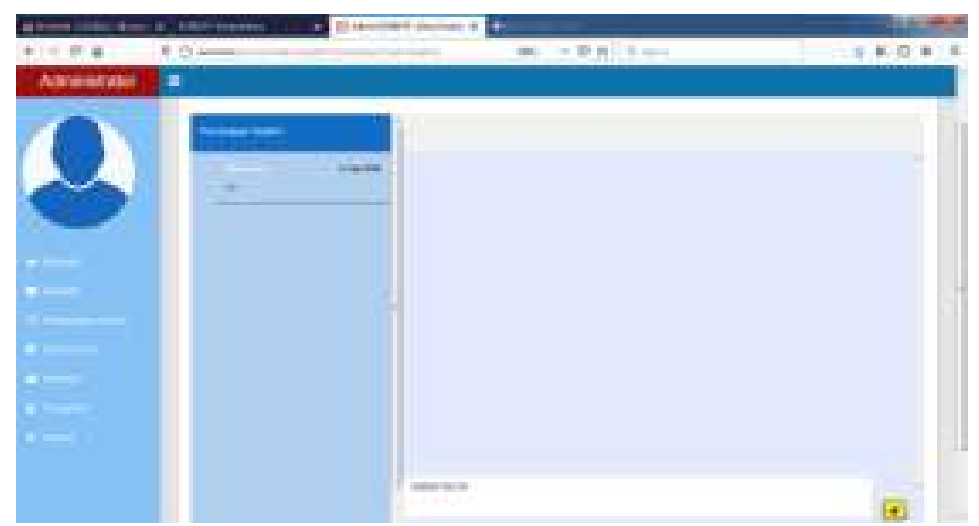

Gambar 9. Tampilan Form Keluhan/ Komplain

7. Tampilan Form Hasil Survey

Tampilan ini merupakan tampilan form Hasil Survey yang berfungsi untuk menampilkan data-data Hasil Survey. Berikut gambar form Hasil Survey ditunjukkan pada 10. :

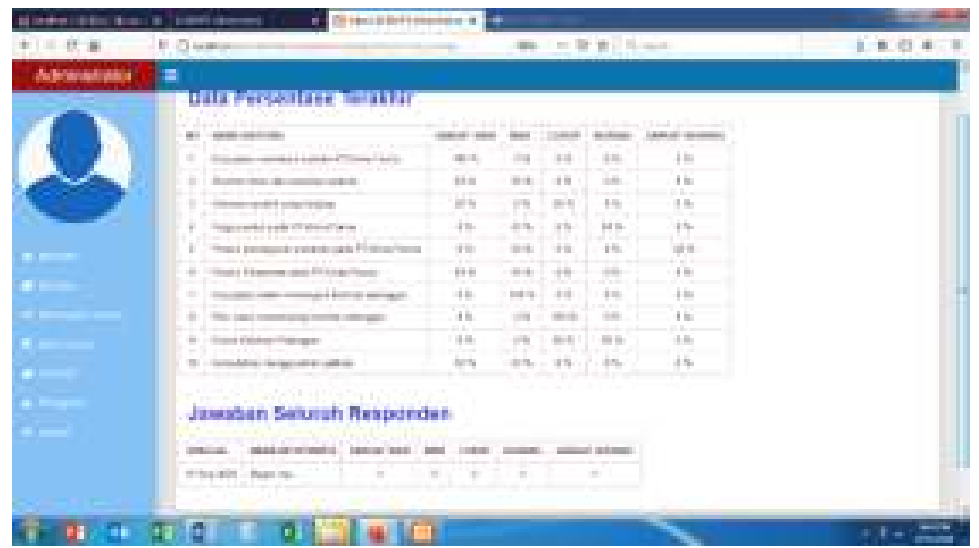

Gambar 10. Tampilan Form Hasil Survey 
Adapun responden atau pelanggan yang menjawab kuisioner adaalah 3 orang dengan jawaban sebagai berikut :

1. Natalia

\begin{tabular}{|l|l|}
\hline Pernyataan & Jawaban \\
\hline PT. Kimia Farmamemberikan pelayanan sesuai yang dijanjikan & $\mathrm{B}$ \\
\hline Pelayanan di PT. Kimia Farmatepat waktu & $\mathrm{B}$ \\
\hline Pemeriksaan, pelayanan di perusahaan dilakukan secara tepat & $\mathrm{C}$ \\
\hline PT. Kimia Farmamemberikan informasi mengenai pelayanan secara jelas & $\mathrm{C}$ \\
\hline Perusahaan menjawab keluhan pelanggan & $\mathrm{B}$ \\
\hline Fitur di website untuk mnampung keluhan pelanggan & $\mathrm{B}$ \\
\hline Diskon atau potongan harga untuk kuantiti banyak & $\mathrm{C}$ \\
\hline $\begin{array}{l}\text { Perushaan didukung dengan tenaga customer service yang handal sehingga dapat } \\
\text { menimbulkan kepercayaan pelanggan }\end{array}$ & $\mathrm{C}$ \\
\hline Pelanggan merasa aman untuk membeli atau memesan produk yang ada di perusahaan & $\mathrm{C}$ \\
\hline Pegawai di perusahaan bersikap sopan kepada pelanggan & $\mathrm{C}$ \\
\hline Perusahaan mampu menjawab pertanyaan yang diajukan pelanggan & $\mathrm{B}$ \\
\hline Perusahaan berusaha menenangkan rasa cemas pelanggan terhadap pelayanan yang diderita & $\mathrm{C}$ \\
\hline perushaan beroperasi 24 jam sehari sehingga pelanggan dapat terlayani & $\mathrm{C}$ \\
\hline Peralatan yang digunakan di Perusahaan terlihat canggih & $\mathrm{C}$ \\
\hline Perusahaan memili alat-alat printing yang cukup lengkap & $\mathrm{C}$ \\
\hline produk yang ditawarkan perusahaan dengan kebutuhan pelanggan sudah sesuai & $\mathrm{C}$ \\
\hline Tarif yang dikenakan perusahaan kepada pelanggan tidak mahal & $\mathrm{C}$ \\
\hline Tarif jasa pelayanan perushaan lebih murah dibandingkan dengan yang lain & $\mathrm{C}$ \\
\hline Perusahaan memberikan diskon atas tarif jasa pelayanan yang diberikan & $\mathrm{B}$ \\
\hline perushaan menteapkan pungutan-pungutan lain diluar tarif yang sudah ditetapkan & $\mathrm{C}$ \\
\hline $\begin{array}{l}\text { Tarif Jasa pelayanan perusahaan sudah sesuai dengan kualitas pelayanan yang diberikan pihak } \\
\text { PT. Kimia Farmakepada para pelanggan }\end{array}$ & $\mathrm{B}$ \\
\hline bentuk brosur yang dibrikan perusahaan sangat menarik & $\mathrm{B}$ \\
\hline Informasi yang erdapat pada brosur yang diberikan perusahaan sangat informatif & $\mathrm{SB}$ \\
\hline
\end{tabular}

\section{Rezeki}

Pernyataan

PT. Kimia Farmamemberikan pelayanan sesuai yang dijanjikan

Pelayanan di PT. Kimia Farmatepat waktu

Pemeriksaan, pelayanan di perusahaan dilakukan secara tepat

PT. Kimia Farmamemberikan informasi mengenai pelayanan secara jelas

Perusahaan menjawab keluhan pelanggan

Fitur di website untuk mnampung keluhan pelanggan

Diskon atau potongan harga untuk kuantiti banyak

Perushaan didukung dengan tenaga customer service yang handal sehingga dapat $\mathrm{B}$

menimbulkan kepercayaan pelanggan

Pelanggan merasa aman untuk membeli atau memesan produk yang ada di perusahaan

Pegawai di perusahaan bersikap sopan kepada pelanggan

Perusahaan mampu menjawab pertanyaan yang diajukan pelanggan

Perusahaan berusaha menenangkan rasa cemas pelanggan terhadap pelayanan yang diderita

perushaan beroperasi 24 jam sehari sehingga pelanggan dapat terlayani

Peralatan yang digunakan di Perusahaan terlihat canggih

Perusahaan memili alat-alat printing yang cukup lengkap

produk yang ditawarkan perusahaan dengan kebutuhan pelanggan sudah sesuai

Tarif yang dikenakan perusahaan kepada pelanggan tidak mahal

Tarif jasa pelayanan perushaan lebih murah dibandingkan dengan yang lain

Perusahaan memberikan diskon atas tarif jasa pelayanan yang diberikan

\begin{tabular}{|l|}
\hline Jawaban \\
\hline SB \\
\hline B \\
\hline B \\
\hline B \\
\hline B \\
\hline B \\
\hline B \\
\hline B \\
\hline B \\
\hline C \\
\hline B \\
\hline B \\
\hline C \\
\hline C \\
\hline C \\
\hline B \\
\hline B \\
\hline B \\
\hline
\end{tabular}




\begin{tabular}{|l|l|}
\hline perushaan menteapkan pungutan-pungutan lain diluar tarif yang sudah ditetapkan & B \\
\hline $\begin{array}{l}\text { Tarif Jasa pelayanan perusahaan sudah sesuai dengan kualitas pelayanan yang diberikan pihak } \\
\text { PT. Kimia Farmakepada para pelanggan }\end{array}$ & $\mathrm{C}$ \\
\hline bentuk brosur yang dibrikan perusahaan sangat menarik & $\mathrm{C}$ \\
\hline Informasi yang erdapat pada brosur yang diberikan perusahaan sangat informatif & $\mathrm{C}$ \\
\hline
\end{tabular}

3. Resti

\begin{tabular}{|l|l|}
\hline Pernyataan & Jawaban \\
\hline PT. Kimia Farmamemberikan pelayanan sesuai yang dijanjikan & $\mathrm{B}$ \\
\hline Pelayanan di PT. Kimia Farmatepat waktu & $\mathrm{B}$ \\
\hline Pemeriksaan, pelayanan di perusahaan dilakukan secara tepat & $\mathrm{B}$ \\
\hline PT. Kimia Farmamemberikan informasi mengenai pelayanan secara jelas & $\mathrm{B}$ \\
\hline Perusahaan menjawab keluhan pelanggan & $\mathrm{B}$ \\
\hline Fitur di website untuk mnampung keluhan pelanggan & $\mathrm{B}$ \\
\hline Diskon atau potongan harga untuk kuantiti banyak & $\mathrm{B}$ \\
\hline $\begin{array}{l}\text { Perushaan didukung dengan tenaga customer service yang handal sehingga dapat } \\
\text { menimbulkan kepercayaan pelanggan }\end{array}$ & $\mathrm{B}$ \\
\hline Pelanggan merasa aman untuk membeli atau memesan produk yang ada di perusahaan & $\mathrm{B}$ \\
\hline Pegawai di perusahaan bersikap sopan kepada pelanggan & $\mathrm{B}$ \\
\hline Perusahaan mampu menjawab pertanyaan yang diajukan pelanggan & $\mathrm{B}$ \\
\hline Perusahaan berusaha menenangkan rasa cemas pelanggan terhadap pelayanan yang diderita & $\mathrm{B}$ \\
\hline perushaan beroperasi 24 jam sehari sehingga pelanggan dapat terlayani & $\mathrm{B}$ \\
\hline Peralatan yang digunakan di Perusahaan terlihat canggih & $\mathrm{B}$ \\
\hline Perusahaan memili alat-alat printing yang cukup lengkap & $\mathrm{B}$ \\
\hline produk yang ditawarkan perusahaan dengan kebutuhan pelanggan sudah sesuai & $\mathrm{B}$ \\
\hline Tarif yang dikenakan perusahaan kepada pelanggan tidak mahal & $\mathrm{B}$ \\
\hline Tarif jasa pelayanan perushaan lebih murah dibandingkan dengan yang lain & $\mathrm{B}$ \\
\hline Perusahaan memberikan diskon atas tarif jasa pelayanan yang diberikan & $\mathrm{B}$ \\
\hline perushaan menteapkan pungutan-pungutan lain diluar tarif yang sudah ditetapkan & $\mathrm{B}$ \\
\hline $\begin{array}{l}\text { Tarif Jasa pelayanan perusahaan sudah sesuai dengan kualitas pelayanan yang diberikan pihak } \\
\text { PT. Kimia Farmakepada para pelanggan }\end{array}$ & $\mathrm{B}$ \\
\hline bentuk brosur yang dibrikan perusahaan sangat menarik & $\mathrm{B}$ \\
\hline Informasi yang erdapat pada brosur yang diberikan perusahaan sangat informatif & $\mathrm{B}$ \\
\hline
\end{tabular}

\begin{tabular}{|c|c|c|c|c|c|}
\hline Responden & Sangat baik & Baik & Cukup & Kurang & Sangat Kurang \\
\hline Resti & 0 & 23 & 0 & 0 & 0 \\
\hline Natalia & 1 & 8 & 14 & 0 & 0 \\
\hline Rezeki & 1 & 15 & 7 & 0 & 0 \\
\hline
\end{tabular}

Untuk pencarian hasil Persentase :

Jumlah Jawaban/ Total Jawabam x 100

Maka diperoleh hasil ;

\begin{tabular}{|c|c|c|c|c|c|c|}
\hline \multirow{2}{*}{ NO } & \multicolumn{5}{|c|}{ SANGAT } & \multirow{2}{*}{$\begin{array}{l}\text { SANGAT } \\
\text { KURANG }\end{array}$} \\
\hline & PERNYATAAAN & BAIK & BAIK & CUKUP & KURANG & \\
\hline 1 & $\begin{array}{l}\text { PT. Kimia Farmamemberikan pelayanan sesuai } \\
\text { yang dijanjikan }\end{array}$ & i $33.33 \%$ & $66.67 \%$ & $0 \%$ & $0 \%$ & $0 \%$ \\
\hline 2 & Pelayanan di PT. Kimia Farmatepat waktu & $0 \%$ & $100 \%$ & $0 \%$ & $0 \%$ & $0 \%$ \\
\hline 3 & $\begin{array}{l}\text { Pemeriksaan, pelayanan di perusahaan dilakukan } \\
\text { secara tepat }\end{array}$ & $0 \%$ & $66.67 \%$ & $33.33 \%$ & $0 \%$ & $0 \%$ \\
\hline 4 & $\begin{array}{l}\text { PT. Kimia Farmamemberikan informasi } \\
\text { mengenai pelayanan secara jelas }\end{array}$ & $0 \%$ & $66.67 \%$ & $33.33 \%$ & $0 \%$ & $0 \%$ \\
\hline 5 & Perusahaan menjawab keluhan pelanggan & $0 \%$ & $100 \%$ & $0 \%$ & $0 \%$ & $0 \%$ \\
\hline
\end{tabular}




\begin{tabular}{|c|c|c|c|c|c|c|}
\hline $\mathrm{NO}$ & PERNYATAAAN & $\begin{array}{l}\text { SANGAT } \\
\text { BAIK }\end{array}$ & BAIK & CUKUP & KURANG & $\begin{array}{l}\text { SANGAT } \\
\text { KURANG }\end{array}$ \\
\hline 6 & $\begin{array}{l}\text { Fitur di website untuk mnampung keluhan } \\
\text { pelanggan }\end{array}$ & $0 \%$ & $100 \%$ & $0 \%$ & $0 \%$ & $0 \%$ \\
\hline 7 & $\begin{array}{l}\text { Diskon atau potongan harga untuk kuantiti } \\
\text { banyak }\end{array}$ & $0 \%$ & $66.67 \%$ & $33.33 \%$ & $0 \%$ & $0 \%$ \\
\hline 8 & $\begin{array}{l}\text { Perushaan didukung dengan tenaga customer } \\
\text { service yang handal sehingga dapat } \\
\text { menimbulkan kepercayaan pelanggan }\end{array}$ & $0 \%$ & $66.67 \%$ & $33.33 \%$ & $0 \%$ & $0 \%$ \\
\hline 9 & $\begin{array}{l}\text { Pelanggan merasa aman untuk membeli atau } \\
\text { memesan produk yang ada di perusahaan }\end{array}$ & $0 \%$ & $66.67 \%$ & $33.33 \%$ & $0 \%$ & $0 \%$ \\
\hline 10 & $\begin{array}{l}\text { Pegawai di perusahaan bersikap sopan kepada } \\
\text { pelanggan }\end{array}$ & $0 \%$ & $66.67 \%$ & $33.33 \%$ & $0 \%$ & $0 \%$ \\
\hline 11 & $\begin{array}{l}\text { Perusahaan mampu menjawab pertanyaan yang } \\
\text { diajukan pelanggan }\end{array}$ & $0 \%$ & $66.67 \%$ & $33.33 \%$ & $0 \%$ & $0 \%$ \\
\hline 12 & $\begin{array}{l}\text { Perusahaan berusaha menenangkan rasa cemas } \\
\text { pelanggan terhadap pelayanan yang diderita }\end{array}$ & $0 \%$ & $66.67 \%$ & $33.33 \%$ & $0 \%$ & $0 \%$ \\
\hline 13 & $\begin{array}{l}\text { perushaan beroperasi } 24 \text { jam sehari sehingga } \\
\text { pelanggan dapat terlayani }\end{array}$ & $0 \%$ & $66.67 \%$ & $33.33 \%$ & $0 \%$ & $0 \%$ \\
\hline 14 & $\begin{array}{l}\text { Peralatan yang digunakan di Perusahaan terlihat } \\
\text { canggih }\end{array}$ & $0 \%$ & $33.33 \%$ & $66.67 \%$ & $0 \%$ & $0 \%$ \\
\hline 15 & $\begin{array}{l}\text { Perusahaan memili alat-alat printing yang cukup } \\
\text { lengkap }\end{array}$ & $0 \%$ & $33.33 \%$ & $66.67 \%$ & $0 \%$ & $0 \%$ \\
\hline 16 & $\begin{array}{l}\text { produk yang ditawarkan perusahaan dengan } \\
\text { kebutuhan pelanggan sudah sesuai }\end{array}$ & $0 \%$ & $33.33 \%$ & $66.67 \%$ & $0 \%$ & $0 \%$ \\
\hline 17 & $\begin{array}{l}\text { Tarif yang dikenakan perusahaan kepada } \\
\text { pelanggan tidak mahal }\end{array}$ & $0 \%$ & $66.67 \%$ & $33.33 \%$ & $0 \%$ & $0 \%$ \\
\hline 18 & $\begin{array}{l}\text { Tarif jasa pelayanan perushaan lebih murah } \\
\text { dibandingkan dengan yang lain }\end{array}$ & $0 \%$ & $66.67 \%$ & $33.33 \%$ & $0 \%$ & $0 \%$ \\
\hline 19 & $\begin{array}{l}\text { Perusahaan memberikan diskon atas tarif jasa } \\
\text { pelayanan yang diberikan }\end{array}$ & $0 \%$ & $100 \%$ & $0 \%$ & $0 \%$ & $0 \%$ \\
\hline 20 & $\begin{array}{l}\text { perushaan menteapkan pungutan-pungutan lain } \\
\text { diluar tarif yang sudah ditetapkan }\end{array}$ & $0 \%$ & $66.67 \%$ & $33.33 \%$ & $0 \%$ & $0 \%$ \\
\hline 21 & $\begin{array}{l}\text { Tarif Jasa pelayanan perusahaan sudah sesuai } \\
\text { dengan kualitas pelayanan yang diberikan pihak } \\
\text { PT. Kimia Farmakepada para pelanggan }\end{array}$ & $0 \%$ & $66.67 \%$ & $33.33 \%$ & $0 \%$ & $0 \%$ \\
\hline 22 & $\begin{array}{l}\text { bentuk brosur yang dibrikan perusahaan sangat } \\
\text { menarik }\end{array}$ & $0 \%$ & $66.67 \%$ & $33.33 \%$ & $0 \%$ & $0 \%$ \\
\hline 23 & $\begin{array}{l}\text { Informasi yang erdapat pada brosur yang } \\
\text { diberikan perusahaan sangat informatif }\end{array}$ & & $33.33 \%$ & $33.33 \%$ & $0 \%$ & $0 \%$ \\
\hline
\end{tabular}

Adapun kesimpulan penulis mengenai kelebihan dari sistem yang diusulkan adalah sebagai berikut :

1. Pada tahap proses penginputan data dan transaksi dapat dilakukan dengan lebih cepat, tepat, akurat dan efisien.

2. Sistem telah didukung dengan sistem basis data modern yang mampu menampung jumlah data dengan kapasitas yang sangat besar, sehingga perusahaan tidak perlu khawatir akan mengalami over capacity data.

Adapun kesimpulan penulis mengenai kekurangan dari sistem yang diusulkan adalah:

1. Sistem hanya terbatas pada pengolahan data hubungan loyalitas inerja perusahaan dengan pelanggan saja, sehingga ketika sistem akan digunakan pada perusahaan yang mempunyai kegiatan yang lebih kompleks (besar), maka sistem tidak akan efektif maupun efesien. 
2. Sistem belum mampu dijalankan pada jaringan client server, sehingga sistem yang dibangun tidak dapat dijalankan pada beberapa komputer/laptop.

\section{KESIMPULAN}

Dengan mempelajari berbagai permasalahan yang ada pada Penerapan E-Customer Relationship Pada PT.Kimia Farma Berbasis Web, maka dapat diambil beberapa kesimpulan antara lain:

1. Minimnya kesalahan yang terjadi dalam pengolahan data loyalitas pelanggan dan dapat mempermudah dan mempercepat dalam melakukan pelayanan konsumen.

2. Sistem yang sedang berjalan pada PT.Kimia Farma telah menggunakan sistem semi komputerisasi sehingga membutuhkan waktu yang lama dalam pencarian, penginputan data maupun dalam pembuatan kuisoner.

3. Perusahaan akan lebih mudah dalam melihat hasil dari pengisian kuisoner yang terjadi dengan sistem yang telah dirancang sehingga meningkatkan kinerja pada PT.Kimia Farma.

\section{SARAN}

Adapun saran-saran yang akan penulis usulkan untuk meningkatkan Penerapan ECustomer Relationship Pada PT.Kimia Farma Berbasis Web adalah sebagai berikut :

1. Sistem yang dirancang oleh penulis belum berbasis client server sehingga hasil pengisian kuisoner yang dperolehan tidak dapat dilihat lebih dari satu PC (Personal Computer).

2. Perlunya proses back up data untuk menjaga kenyamanan data.

3. Bila sistem yang penulis usulkan nantinya bisa dikembangkan dengan sistem komputerisasi hendaknya dapat melakukan pelatihan dan menyertakan spesifikasi dari sistem seperti yang telah penulis jelaskan didalam penelitian ini.

\section{UCAPAN TERIMA KASIH}

Penulis mengucapkan terima kasih kepada Universitas Potensi Utama yang telah banyak memberikan masukkan dan saran dalam penyelesaian penelitian ini.

\section{DAFTAR PUSTAKA}

[1] Solichin, A. (2016). Pemrograman web dengan PHP dan MySQL. Penerbit Budi Luhur.

[2] Afrina, M., \& Ibrahim, A. (2013). Rancang Bangun Electronic Costumer Relationship Management (E-CRM) Sebagai Sistem Informasi Dalam Peningkatan Layanan Perpustakaan Digital Fakultas Ilmu Komputer Unsri. Jurnal Sistem Informasi (JSI), 5(2), 629-644.

[3] Anwar, S., Efendi, Y., Rustam, R., \& Andrew, A. (2016). Perancangan Sistem Informasi Pendaftaran Mahasiswa Baru dan Pengisian Kartu Rencana Studi (KRS) AMIK Wahana Mandiri Berbasis Web Mobile. Studia Informatika: Jurnal Sistem Informasi, 9(1).

[4] Aprianti, W., \& Maliha, U. (2016). Sistem Informasi Kepadatan Penduduk Kelurahan Atau Desa Studi Kasus Pada Kecamatan Bati-Bati Kabupaten Tanah Laut. Jurnal Sains dan Informatika, 2(1).

[5] Rahman, A. A., Supaidi, A., Aslamiah, I., \& Ibrahim, A. (2018). Implementasi Customer Relationship Management (Crm) Pelayanan Pelanggan (Corporate) Divisi Bges Pada Pt Telkom Witel Sumsel. JRMSI-Jurnal Riset Manajemen Sains Indonesia, 9(1), 72-78.

[6] Candra, C. (2017). Perancangan Mebel Multifungsi untuk "Daily Treats" Surabaya. Intra, $5(2), 322-331$. 
[7] Ekadiansyah, E., \& Kurniawan, H. (2015). PERANCANGAN E-CRM (CUSTOMER RELATIONSHIP MANAGEMENT) PADA PT. SONYA FM MEDAN. SEMNASTEKNOMEDIA ONLINE, 3(1), 3-3.

[8] Darmawan, H., Ari, O., \& Aditya, A. (2018, July). Analisis dan Perancangan Electronic Customer Relationship Management pada Cetta Mom and Baby Spa Pontianak. In Proceeding Seminar Nasional Sistem Informasi dan Teknologi Informasi (Vol. 1, No. 1, pp. 611-615).

[9] Adnyana, I. M. B. (2016). Perancangan Sistem Informasi Akademik STIKES Wira Medika Bali Berbasis Desktop. Jurnal Sistem dan Informatika (JSI), 10(2), 49-58.

[10] Linda, D. (2016). Analisis Sistem Informasi Pengawas Keamanan dan Kesehatan Makan pada Dinas Kesehatan Kota Bandar Lampung. EXPERT: Jurnal Manajemen Sistem Informasi dan Teknologi, 6(2).

[11] Munte, M. H. M. (2016). Sistem Informasi Akuntansi. Edisi Pertama Universitas HKBP Nommensen

[12] Sutopo, P., Cahyadi, D., \& Arifin, Z. (2017). Sistem Informasi Eksekutif Sebaran Penjualan Kendaraan Bermotor Roda 2 di Kalimantan Timur Berbasis Web.

[13] Yesputra Rolly, 2017. Belajar Visual Basic .Net Dengan Visual Studio 2010. Royal Asahan Press, Kisaran.

[14] Mulyani, S. (2017). Metode Analisis dan perancangan sistem. Abdi Sistematika.

[15] Musrifah, M. (2017). Implementasi Teknologi Informasi Menggunakan Human Organization Technology (HOT) Fit Model di Perpustakaan Perguruan Tinggi. JIPI (Jurnal Ilmu Perpustakaan dan Informasi), 2(2), 222-242. 